\title{
Linkages of Financial Efficacy, Demographics, Risks Preference and Consumption Behavior in Malaysia*
}

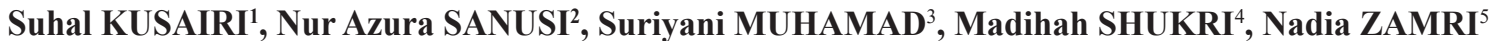

Received: June 24, 2020 Revised: July 12, 2020 Accepted: August 10, 2020

\begin{abstract}
Financial literacy is one of the sustainable development goals of huge concern of governments. Governments explore solutions addressing policies to improve financial literacy. Nevertheless, financial management has such a broad scope and is not just limited to knowledge. As human nature, individuals are born with different confidence levels that include various financial abilities. This study aims to investigate the household-financial efficacy through the application of psychometric instruments, risk preference, and demographic characteristics toward consumption decision behavior. The research is based on a survey 479 households in the peninsular Malaysia, and utilizes the structural equation model, cluster proportional and systematic random sampling, and two measurements - composite reliability and average variance extracted. Results show that households' financial efficacy is one of the critical factors that explain the households' consumption decision behavior. Also, risk preference, gender and area location (rural or urban) of the household determined the consumption decision behavior of the household. The effectiveness of consumption decision is not only determined by financial literacy, but also financial efficacy. The implications of this paper may help to design policies in narrowing the broad gap between the rural and urban level of financial efficacy. The government needs to take appropriate actions to fix it.
\end{abstract}

Keywords: Consumption Behavior, Financial Efficacy, Demographics, Risks Preference

JEL Classification Code: G41, D12, D14

\section{Introduction}

\section{*Acknowledgement:}

This study was funded by the Fundamental Research Grant Scheme (FRGS) Vot-59447. We would like to thank the Minister of Higher Education of Malaysia for financial support.

${ }^{1}$ First Author and Corresponding Author. Department of Economics, Faculty of Business, Economics and Social Development, Universiti Malaysia Terengganu, Malaysia [Postal Address: $1^{\text {st }}$ Floor, FBESD, Kuala Nerus, Terengganu 21030, Malaysia]

Email: suhal@umt.edu.my

2Department of Economics, Faculty of Business, Economics and Social Development, Universiti Malaysia Terengganu, Malaysia. ${ }^{3}$ Department of Economics, Faculty of Business, Economics and Social Development, Universiti Malaysia Terengganu, Malaysia. ${ }^{4}$ Department of Psychology and Counselling, Faculty of Business, Economics and Social Development, Universiti Malaysia Terengganu, Malaysia.

${ }^{5}$ Department of Economics, Faculty of Business, Economics and Social Development, Universiti Malaysia Terengganu, Malaysia.

(c) Copyright: The Author(s)

This is an Open Access article distributed under the terms of the Creative Commons Attribution Non-Commercial License (https://creativecommons.org/licenses/by-nc/4.0/) which permits unrestricted non-commercial use, distribution, and reproduction in any medium, provided the original work is properly cited.
Consumption directly addresses people's living standard or lifestyle. Although the price of goods and services increases from time to time, households cannot avoid consuming. The increasing price of goods and services become dominant and affecting households, especially among low-income households. The households spend their income mostly on consumer goods, which is consist of durable and non-durable goods. Food inflation, in particular, has risen faster than overall inflation (Ramiah et al., 2015). This increment of the basic needs, including durable and nondurable goods, lead to an increase in household debt. As a result, households are facing financial problems. The central bank reported that the household debt ratio of Gross Domestic Product reached $83.8 \%$ in the first half of 2018. Based on the findings of a Malaysia Youth Research Institute, factors that influence spending patterns are $38.2 \%$ determined by income, $26 \%$ by own needs, $11 \%$ by own preference, $23 \%$ by household, $1 \%$ by friends, and $0.5 \%$ by other items. Looking at the pattern of spending, more than $50 \%$ was determined by the factors related to individuals and households themselves. Therefore, self-efficacy could be the aid kit that will provide a broad change in consumption pattern by household. 
We realize that consumption decision-making in the circumstance of limited income and high living cost and financing problems is due to consumer loan decision. It is also closely related to the weak financial management in households consumption decision. If the bottom or lower $40 \%$ income group (B40) households remain in their current socioeconomic position, it will become a social cost to the nation by reducing the necessary skilled workforce and affecting the growth of national output. Therefore, the financial decision is essential for the stability of the households in facing financial challenges and be less reliant on any instalment method that is likely to increase their burden in the future.

Nevertheless, the effectiveness of consumption decision will not be able to be determined by prices and income only. Under certain budget constraints, individual ability must be viewed as the other influential factor that will lead someone to make the best decision regarding consumption activity. The roots of decision-making are related to an element of selfbelief (Scholz et al., 2002). Some experts of behavior finance introduce the self-belief concept that generally explains how a psychological element that exists in inner thought might be one of the restructuring tools in someone's life. Finally, this behavior will be enhanced and end up enabling an individual to manage his financial matters constructively. This kind of positive element will produce positive results that will create a parallel impact on any activity in daily human life. The successful person is the one that believes there might be a successful end to any decision. In psychology, self-belief could call be as self-efficacy (Bandura, 1977). Farrell et al. (2016) supported that financial efficacy is the factor which differentiates households in terms of wealth in the face of normal or recessionary conditions. Also, risk-return tradeoff consideration will determine the effectiveness of households' decision, either in financial asset or consumption related to financing decision.

Existing research shows that the effectiveness of individual investment decisions refers more to financial instruments and saving, such as debt (Forbes and Kara, 2010). Nevertheless, the existing studies rarely look at the household as a whole, as an economic agent through a contract theory between husband, wife, and family members operating as a firm with a collection contract between shareholders. Thus, the objective of this study is to analyze the relationship between financial efficacy, demographic characteristics, risk preferences and consumption decision behavior. The research will focus on an individual's capability to enter into the household contract and the effect on the household's consumption decision. The rational argument is that father and mother or family members may influence the abilities of individuals in making financial and economic decisions (Bandura et al., 2014; Farrell et al., 2016).

The rest of the investigation will be organized as follows: 2) the literature review will discuss on behavioral finance and empirical findings; 3) the methodology will explain about data collection and sources, the definition of a variable, and specification model such as structural equation modelling (SEM); 4) results are analyzed; and 5) conclusion and implications are provided.

\section{Literature Review}

We need to bear in mind that different households tend to react to this mainstream activity, namely, consumption, in ways and behavior that suit their circumstances. Studies that combining both economics and psychology by explaining its interrelationship referred to as behavioral finance seems to be gaining popularity nowadays. Known as market anomalies inefficient market hypothesis or irrational behavior - these studies try to understand how people forget fundamentals and make decisions based on sentiments and emotions. The two building blocks of behavioral finance are cognitive psychology and the limits to arbitrage when markets will be inefficient (Ritter, 2003). This knowledge could be expanded as the other view or as an antonym, as an inefficient market hypothesis and irrational behavior.

The efficient markets model acts as the best "academic" model and does not describe observed movements in financial prices (Shiller 1981). People overreact systematically to dramatic news events, which results in substantial inefficiencies in the stock market. Yaari (1987) suggests that utility theory modifies expected utility theory to obtain the "dual theory of choice under risk". Smuelson and Zechauser (1988) showed that decision-making experiments confirm the presence of status quo bias. According to Kahneman et al. (1990), loss aversion and endowment effect persist even in market settings with opportunities to learn. Ramiah et al. (2015) and Nguyen and Pham (2018) developed noise trading theory and stated that there is a heterogeneous capital market where noise traders tend to distort certain principles of finance. Phan, Le, and Nguyen (2020) studied the overconfidence of investors and returns. This theory is the condition where the behavioral efficient market hypothesis exists.

When looking at numerous theoretical disputes and postulates, some research leans on this kind of behavioral finance towards consumption nowadays. McGuire (1976) studied some internal psychological factors influencing consumer choice. He analyzes directive, informationprocessing aspects of the personality in terms of eight successive steps: exposure, perception, comprehension, agreement, retention, retrieval, decision-making, and action. Barberis and Thaler (2002) surveyed behavioral finance and found financial and economic phenomena can plausibly be understood using models in which some agents are not entirely rational. Gajjar (2013) studied factors affecting consumer behavior and found that it is difficult to predict, 
even for experts in the field. Ramya and Ali (2015) studied factors affecting consumer buying behavior. They agreed that too many factors rely on consumer behavior and stated that an individual consumer is led by culture, subculture, social class, membership groups, family, personality, psychological factors, and cultural trends, as well as social and societal environment.

Ghali and Toukabri (2014) stated that the researcher needs a better understanding of the behavior of the poor consumers. They found that the consumption among the poor is more utilitarian and rational because they are impoverished, but not destitute, and it is used often for credits and overconsumption. This article highlighted the behavior of these consumers, their unexpected needs and their unstable expectations. Pangaribowo (2011) studied the consumption behavior of the poorest and policy implications in Indonesia. They realised that improving household food consumption involves a multitude of issues. This article highlighted the characteristics of the poorest households that were interconnected with their food consumption behavior.

Related to the standard theory of self-efficacy and individual behavior, Bandura (1994) stated that the basic concept of self-efficacy refers to an individual's sense of self-agency, borne out in a belief that they can accomplish a given task and more broadly cope with life challenges. Self-efficacy can be expressed through various elements of individual behaviors, such as how well an individual persevers in the face of adversity, stress or negative shock, whether they have an excellent capability to absorb the kind of pressure from the external or internal factors. In other words, they have an optimistic or pessimistic attitude about the future, and they think in self-enhancing or selfdebilitating ways (Bandura, 2006).

In the application of self-efficacy in economic or financial decision behavior as well, it could be argued that individual who has a greater sense of self-assuredness in their expenditure and financial management capacities are more likely to approach any economic and financial difficulties they encounter as "challenges mastered, rather than as threats to be avoided' (Farrell et al., 2016). Such a positive attitude is likely to result in achievement and, consequently, more favorable individual financial outcomes. Besides, the application of financial self-efficacy concept in a standard model of economic behavior was conducted as the independent variable to evaluate its significance in predicting investigated behavioral outcomes. Previous studies have assessed the explanatory power of the related concepts of 'economic self-efficacy' (Graboski et al., 2001), and 'entrepreneurial self-efficacy', (Kickul et al., 2008). Generally, such results show that the financial self-efficacy could explain favorable individual economic outcomes.

\section{Methodology}

\subsection{Research - Conceptual Framework}

This research integrates a psychological construct (selfefficacy and household efficacy) to understand the behavior of economic agents, focusing on the consumption decision and psychometric application. The effect of self-efficacy on the consumption decision combined with an analysis extended to the effect of family efficacy, could be called as household efficacy on consumption decision as well. Also, demographic factors and risk preference tend to play their role.

Figure 1 explains the conceptual framework of B40 households financial efficacy. As shown, there are four ovals named as Consumption, Individual Efficacy, Households Efficacy and Risk Preference. This oval shape of the framework drawn represents latent or unobserved variables. An unobserved variable, however, is the variable that directly cannot be seen or directly measured. It could be identified as dependent or independent variable; however, as mentioned in the literature, this research treats consumption as dependent variable and the others as independent variables. One variable is drawn in the rectangle shape, namely, demographic factors. This variable will stand as an observed variable or known as a measured variable. The variables that lie under demographic variables are gender and area, which are segregating urban and rural (area) and male and female (gender).

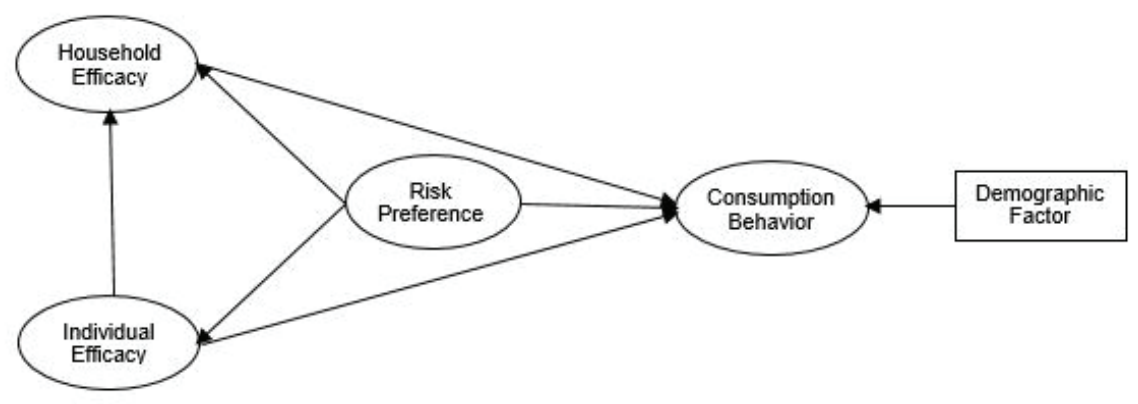

Figure 1: Conceptual Framework of Financial Efficacy and Consumption Behavior 
Fabelo et al. (2013) studied the consumption of alcohol and tobacco and found that the higher the self-esteem, the lower the alcohol and tobacco consumption. The lower alcohol and tobacco consumption could be viewed as positive manners, and thus, this hidden effect could be explored and hence prove that tactical consumption is determined by the self-efficacy of an individual. In healthcare decisions, Strecher et al. (1986) reported that self-efficacy plays a significant role in determining an individual's adherence or self-efficacy towards healthy behavior change. Finally, self-efficacy had been focusing on the relationship among consumers in presenting the degree of their performance (Bozoian, Rejeski, and McAuley, 1994). It is implied that effectiveness of self-efficacy affects the performance of an individual.

Efficacy seems to benefit the way households react toward consumption activity. By avoiding a focus on a small part of consumption, this study looks at both sides of consumption that consist of the consumption of durable goods and nondurable goods. How individual efficacy will affect household efficacy is a new development of this research; past studies do not point to this direction when it comes to financial matter and how the efficacy of individual will affecting household. This will be the novel contribution of this model. Trent and South (2003) stated that personal attitudes might be one of the influential factors that will affect interpreting behavior in the family. In line with this, Minuchin (1985) wrote that by treating the family as an organized system, individuals in them would bring considerable contribution.

Directly, individual financial efficacy will determine the behavior of as someone in the behavior of family member who will act as a role model that will give the guidance on how to manage specific activities carried out by all the persons named as a family. A family is considered a group of two or more persons related by blood, marriage or even adoption. Because families are the closest first guidance to all people in this wide world, it will directly affect and draw a highly significant and positive relationship toward self-efficacy and, thus, reflects the decision of financial households' efficacy. An individual in the family will determine how others in their family should act. Positive personal influential at the beginning will grab other members and train them on how to be successful in managing house cores relating to financial affairs and, thus, the positive financial efficacy will lead to efficient financial management of households.

Human beings are confronted with many choices in daily life, and hence bear the consequences of the decisions they make. Among a married couple, the decision will not only made by one individual. A recent study documents that unhappy people in a marriage are often those who make a decision alone (Madden, 2014). Therefore, inclusive decision-making among married couples is essential.
By assuming that positive and high self-efficacy of an individual will be able to form the basis of efficiency for consumption and saving, we believe that it also significantly affects their spouse as well. As a result, the better decisionmaking in consumption will be the final gain. This arrow from individual efficacy pointed to latent variable denotes that household efficacy comes in the belief of an individual (decision maker) toward their spouse. We will discover the effectiveness of consumption decision when taking into account more than one individual. In a broad view, in the case of consumption, this research implies that the positive vibes of self-efficacy affect people in B40 households in Malaysia and discovers the effectiveness of them.

The relationship between consumption and risk preference is also concerned by this study. Risk preference is the tendency to choose a risky or less risky option. Generally, economists and financial professionals apply the concept of risk preference for investment and financial decisions. Here, our research applies the risk preference as personal preference. An individuals' personality measures personal preference of risk, and how they are willing to take a financial risk if they had some spare cash for a consumption activity. Chetty and Szeidl (2007) showed that consumption commitments can be linked to risk aversion when there is an increasing commitments towards consumption. This leads to a negative relationship between both variables. If the ability to bear risk increases, household tends to delay buying things. This relationship is portrayed by Hassler (1996).

Besides, various studies adopted demographics and discover how this kind of factors will influence the research outcome. Demographics are the characteristics of respondent related to social and demographic factors such as household income, gender, ethnic, ages, education, location (rural or urban), dependency ratio, marriage status, decisionmaker, etc. Hussain et al. (2016) studied the effects of some selected demographic and socioeconomic variables on labor force participation. Hopkins (2014) also studied how gender could give and stretch to borrowing and proved that women are stretching their expenses more than men. There is a significant effect on gender and consumption (Roberts, 1998). There is no support for the direct association between board gender diversity and sustainability performance (Fakir and Jusoh, 2020).

An overall investigation will use Structural Equational Model (SEM). Lower income (B40) groups rarely make a big-ticket purchase. Some of these differences are easily noticeable, whereas others might be a little difficult to observe. Referring to the research strategy, the next step is to determine the constructs and elucidate how there will be operationalized into scale items. 


\subsection{Structural Equation Model Specification}

After rearranging the formula for the first latent variable named Consumption, the model has i-indicators classified into two different groups, Durable Goods (DG) and NonDurable Goods (NDG), formulated as below:

$$
\begin{aligned}
& Q_{i}=\sum_{i=1}^{n} \lambda_{i} N D G_{i}+\delta_{i} \\
& Q_{i}=\sum_{i=1}^{n} \lambda_{i} D G_{i}+\delta_{i}
\end{aligned}
$$

The question 1 and question 2 are combined into the formative measurement models:

$$
\operatorname{CONS}_{i}=\lambda_{11} D G_{i}+\lambda_{21} N D G_{i}+\delta_{i}
$$

Where CONS represents consumption that could be divided into two measurement items, Durable Goods and Non-Durable Goods. It also will simply explain that durable and non-durable goods will measure latent variable consumption.

The second latent variable is the individual efficacy (IE) modeled as i-indicators. The third latent variable is the households' efficacy (HE) modeled as i-indicators. The fourth latent variable is risk preference (RISKP) modeled as i-indicators, represented by equation 4 to 6 as follows:

$$
\begin{aligned}
& Q_{i}=\sum_{i=1}^{n} \lambda_{i} I E_{i}+\delta_{i} \\
& Q_{i}=\sum_{i=1}^{n} \lambda_{i} H E_{i}+\delta_{i} \\
& Q_{i}=\sum_{i=1}^{n} \lambda_{i} R_{I S K P_{i}}+\delta_{i}
\end{aligned}
$$

Where the observed variable denoted by $i, \lambda$ is the loading factor of an observed variable to latent variable, and $\delta$ error measurement model. Then, the formula for endogenous variables, is as follows:

$$
\text { CONS }=\Lambda_{11} I E_{i}+\Lambda_{21} H E_{i}+\Lambda_{31} R I S K P_{i}+\varsigma_{i}
$$

Where CONS represents Consumption, IE represents Individual Efficacy, HE represents Household Efficacy, and RISKP represent Risk Preference.

\subsection{Operationalization Variables}

Consumption is the use of goods and services by households. Consumption is distinct from consumption expenditure, which is the purchase of goods and services for use by households. According to Terano et al. (2016), the primary consideration factor of consumption decision is location, spending on money, and goods and services. Two categories, types of goods sold and price, are given (Terano et al., 2016). With regards to location, it could be said that households are often confused in deciding between Traditional and Modern Market. The selection of location often chosen by B40 households is whether it is modern or traditional market according to price selection, distance, brand and facilities provided. In terms of method of payment, a consumer uses cash to monitor liquidity implications for payments, currency demand and withdrawal behavior (Kalckreuth et al., 2011). In relation to spending, the money method of payment is whether it is in cash or instalment method for specific reasons. Consumer goods are classified into two categories, depending on their durability (O'Brien, 2007). In this case, goods and services classification of durable and non-durable goods. This construct was measured by a 12-point Likert scale ('totally disagree' to 'totally agree').

Individual Efficacy. In general, we can define the selfefficacy as the belief in one's competence to cope with a broad range of stressful or challenging demands, whereas specific self-efficacy refers to a particular task at hand (Luszczynska et al., 2005), refers to an individual's sense of self-agency, borne out in a belief that they can accomplish a given task and more broadly cope with life challenges (Bandura, 1994) and is related to one's ability to cope with some of the situation (Farrell et al., 2016). It is measured by how far a person believes in their capability in deciding financial matters, including spending and saving, denoted as main activities of daily life. The high financial self-efficacy will reflect that one has high self believes. This construct was measured by a 10-point Likert scale, from 'totally disagree' to 'totally agree' adapted from Lown (2011).

Household Efficacy refers to collective financial efficacy, which consists of a husband, his wife, and their family, describe that the households' perceived ability to manage their finances (Kusairi et al., 2019). Nolan et al. (2009) stated how household belief in their spouse making healthcare decisions. It is measured by how far a person believes in their capability in deciding financial matters, including spending and saving, denoted as main activities of daily life. The high financial self-efficacy will reflect that one has high self believes. This construct was measured by a 4-point Likert scale ('totally disagree' to 'totally agree'). This measurement was derived from Lown (2015).

Risk Preference could be divided into stages of the risk. 1) Daily risk. The primary risk that households might face in their daily life, and it is an unpredictable and light risk (Campbell, 2006). Light risk or shocks faced by household every day, for example, immediate need for money to buy such cooking gas. 2) Idiosyncratic risk. It mostly affects assets that an individual's or company got. Usually it means 
assets that households has. For instance, fixing a car, house repairing cost or health cost. 3) Covariant risk. It affects groups of household, communities, regions or even entire countries. A considerable risk might cause a loss affecting an individual or his family and even caused by the economic situations like unemployment and disaster. This construct was measured by a 3-point Likert scale ('totally disagree' to 'totally agree').

\subsection{Sampling and Data Collection Technique}

Survey and ground research are used. Unit of analysis in this research is upper B40 household from urban and rural areas, from various ethnicities: Malay, China and India in Peninsular of Malaysia. The population frame is B40 household from three urban areas and three rural areas, consisting of the main ethnicities: Malay, China and India. They are present in all socioeconomic levels in Peninsular Malaysia.

Sampling technique is cluster proportional and systematic random sampling to capture the characteristics of the population. In order to get reliable and valid results for characteristics of the population, the minimum sample will be determined. Then, it will be distributed based on proportional allocation. The population is clustered based on states and urban areas. Significance level, standard error and the total population of each cluster, and bound of error are considered. The research sample consists of 479 respondents from B40 households.

Data collection techniques use questionnaire. The questionnaire is given to all selected respondents of B40 household. Closed questions are used and the options are given using Likert scale model (see, appendices A-D). The items of questionnaires are constructed based on a strong definition, determinant of dimension, and how to measure every variable. It is a critical step of survey research to ensure the items of the questionnaire are related to the main issues being studied.

\section{Results and Discussion}

The discussion starts with a descriptive analysis of the main variables, followed by the analysis of households' financial-efficacy, demographic characteristics and risk preference towards consumption decision behavior.

\subsection{Descriptive Statistics Analysis of Households}

Table 1 indicates the distribution of respondents from B40 households in the selected peninsular area of Malaysia. This investigation could be explained as urban monopoly as 368 respondents $(76.8 \%)$ come from urban areas compare to 111 respondents $(23.2 \%)$ coming from rural areas. In terms of gender, female respondents account for $64.5 \%$ (307). It is in line with the fact that females take care of the household and make most of the decisions about the house affairs. Male respondents account for $35.5 \%$ (172) of the sample. There are various ethnicities in Malaysia. Malays, however, account for the large percentage, $81.94 \%$, with 392 respondents. Indians follow with $10.23 \%$ (49), then Chinese with $6.06 \%$ (29); the remaining nine respondents represent $1.88 \%$.

About the educational background of B40 households, 40 respondents went to primary school $(8.4 \%)$. The majority of respondents, $65.8 \%,(315)$ only received an education until secondary school. 118 respondents $(24.6 \%)$ received a college and university-level tertiary education, and six respondents $(1.3 \%)$ never attend school.

Table 1: Distribution of Respondents

\begin{tabular}{|l|l|c|c|c|}
\hline & \multicolumn{1}{|c|}{ Category } & Frequency & Percent & Cumulative \\
\hline Area & Rural & 111 & 23.20 & 76.80 \\
& Urban & 368 & 76.80 & 100.00 \\
\hline Gender & Male & 172 & 35.50 & 35.50 \\
& Female & 307 & 64.50 & 100.00 \\
\hline Race & Malay & 392 & 81.94 & 81.94 \\
& Chinese & 29 & 6.05 & 87.99 \\
& Indian & 49 & 10.23 & 98.22 \\
& Others & 9 & 1.88 & 100.00 \\
\hline \multirow{2}{*}{ Education } & Never attend & 6 & 1.3 & 1.3 \\
& Primary & 40 & 8.40 & 9.60 \\
& Secondary & 118 & 24.80 & 75.40 \\
& Tertiary & & 100.00 \\
\hline
\end{tabular}




\subsection{Reliability and Validity of Test Analysis}

Table 2 depicts the results of items analysis that had been developed based on the definition of each of the constructs. If the factors (dimensions) appear lacking the validity and reliability, it could signals that the item should be excluded in the causal model. This paper is adapting two measurements that can be useful for establishing validity and reliability, namely, Composite Reliability (CR) and Average Variance Extracted (AVE).

We deleted the bold items denotes IE1, NDG1, NDG2 and NDG7 as they give low factor loading. As suggested by Tabachnick and Fidell (2007) and Comrey and Lee (1992), it is important to use more stringent cut-offs, going from 0.32 (poor), 0.45 (fair), 0.55 (good), 0.63 (very good) to 0.71 (excellent). All items denote value higher than 0.5 for AVE and higher than 0.6 for CR. This value is supported by
Fornell and Larcker (1981) that stated if AVE is less than 0.5, but composite reliability is higher than 0.6 , the convergent validity of the construct is still adequate.

Table 3 shows the discriminant validity index where AVE square root for the construct could be represented by the diagonal and the remaining value represents the correlation between the construct on the row and column. We can consider the discriminant validity achieved when the value on the diagonal is higher than the value in the row and its column. The table shows the first variable, Individual Efficacy with a validity index of 0.784 , which is higher than 0.619 and $0.770,0.615,0.421$ and 0.674 . The second variable, Durable Goods, has a value of 0.719 , which is higher than other values. Next is Household Efficacy, at 0.818 , which is greater than 0.159 and 0.705 . Last, but least, the dependent variable consumption denoted Non-Durable Goods was 0.712 .

Table 2: Average Variance Extracted (AVE) and Composite Reliability (CR)

\begin{tabular}{|l|c|c|c|c|l|l|l|l|l|}
\hline Construct & Item & $\begin{array}{c}\text { Loading } \\
\text { Factor }\end{array}$ & AVE & CR & Construct & Item & $\begin{array}{c}\text { Loading } \\
\text { Factor }\end{array}$ & AVE & CR \\
\hline Individual & IE1 & 0.480 & 0.62 & 0.94 & Durable & DG1 & 0.760 & 0.52 & 0.88 \\
\hline Efficacy & IE2 & 0.740 & & & Goods & DG2 & 0.610 & & \\
\hline & IE3 & 0.800 & & & & DG3 & 0.650 & & \\
\hline & IE4 & 0.780 & & & & DG4 & 0.700 & & \\
\hline & IE5 & 0.700 & & & & DG5 & 0.600 & & \\
\hline & IE6 & 0.780 & & & & DG6 & 0.690 & & \\
\hline & IE7 & 0.880 & & & & DG7 & 0.700 & & \\
\hline & IE8 & 0.830 & & & Non- & NDG1 & 0.450 & 0.51 & 0.80 \\
\hline & IE9 & 0.830 & & & Durable & NDG2 & 0.480 & & \\
\hline & IE10 & 0.700 & & & Goods & NDG3 & 0.650 & & \\
\hline Household & HE1 & 0.780 & 0.67 & 0.89 & & NDG4 & 0.880 & & \\
\hline Efficacy & HE2 & 0.820 & & & & NDG5 & 0.640 & & \\
\hline & HE3 & 0.830 & & & & NDG6 & 0.730 & & \\
\hline RISK & HE4 & 0.840 & & & & NDG7 & 0.190 & & \\
\hline & RISK1 & 0.810 & 0.60 & 0.82 & & & & & \\
\hline & RISK2 & 0.770 & & & & & & & \\
\hline
\end{tabular}

Table 3: The Discriminant Validity Index Summary for the main five constructs.

\begin{tabular}{|l|c|c|c|c|c|}
\hline Construct & Individual Efficacy & Durable Goods & Household Efficacy & RISK & Non-Durable Goods \\
\hline Individual Efficacy & 0.784 & & & & \\
\hline Durable Goods & 0.619 & 0.719 & & & \\
\hline Household Efficacy & 0.615 & 0.643 & 0.818 & & \\
\hline Risks Preference & 0.421 & 0.113 & 0.159 & 0.777 & \\
\hline Non-Durable Goods & 0.674 & 0.626 & 0.705 & 0.213 & 0.712 \\
\hline
\end{tabular}




\subsection{Linkages of Financial Efficacy, Demographics, Risk Preference and Consumption Behavior}

Table 4 shows the results of unstandardized structural equation model for the whole model and demographic characteristics. For the whole model, risks have a significant positive effect on the individual efficacy at $1 \%$. Since the unstandardized coefficient represents the amount of change in the dependent variable per single unit change in the predictor variable, the result suggests that for every single unit increase in risk, individual regression estimate value is 0.658 at $1 \%$ significant level. For every single unit increase

Table 4: Regression Weight for Structural Model

\begin{tabular}{|c|c|c|c|c|c|c|}
\hline \multirow{2}{*}{\multicolumn{7}{|c|}{$\begin{array}{l}\text { Regression } \\
\text { Whole Model }\end{array}$}} \\
\hline & & & & & & \\
\hline IE & $<--$ & RISK & 0.375 & 0.052 & 7.146 & 0.000 \\
\hline HOEF & $<--$ & IE & 0.658 & 0.058 & 11.292 & 0.000 \\
\hline HOEF & $<--$ & RISK & -0.121 & 0.036 & -3.337 & 0.000 \\
\hline CONS & $<--$ & HE & 0.389 & 0.055 & 7.093 & 0.000 \\
\hline CONS & $<--$ & IE & 0.434 & 0.058 & 7.415 & 0.000 \\
\hline CONS & $<--$ & RISK & -0.109 & 0.052 & -7.146 & 0.000 \\
\hline \multicolumn{7}{|c|}{ Demographic Differentiation (Urban) } \\
\hline IE & $<--$ & RISK & 0.356 & 0.063 & 5.632 & 0.000 \\
\hline HOEF & $<--$ & IE & 0.630 & 0.068 & 9.238 & 0.000 \\
\hline HOEF & $<--$ & RISK & -0.115 & 0.044 & -2.641 & 0.008 \\
\hline CONS & $<--$ & $\mathrm{HE}$ & 0.436 & 0.063 & 6.892 & 0.000 \\
\hline CONS & $<--$ & IE & 0.420 & 0.066 & 6.366 & 0.000 \\
\hline CONS & $<--$ & RISK & -0.100 & 0.037 & -2.674 & 0.008 \\
\hline \multicolumn{7}{|c|}{ Demographic Differentiation (Rural) } \\
\hline IE & $<--$ & RISK & 0.474 & 0.094 & 5.035 & 0.000 \\
\hline HOEF & $<--$ & IE & 0.744 & 0.112 & 6.66 & 0.000 \\
\hline HOEF & $<--$ & RISK & -0.18 & 0.071 & -2.539 & 0.011 \\
\hline CONS & $<--$ & $\mathrm{HE}$ & 0.246 & 0.048 & 5.095 & 0.000 \\
\hline CONS & $<--$ & IE & 0.494 & 0.131 & 3.783 & 0.000 \\
\hline CONS & $<--$ & RISK & -0.146 & 0.066 & -2.204 & 0.027 \\
\hline \multicolumn{7}{|c|}{ Demographic Differentiation (Male) } \\
\hline IE & $<--$ & RISK & 0.317 & 0.099 & 3.203 & 0.001 \\
\hline HOEF & $<--$ & $\mathrm{IE}$ & 0.479 & 0.095 & 5.014 & 0.000 \\
\hline HOEF & $<--$ & RISK & 0.000 & 0.066 & 0.004 & 0.997 \\
\hline CONS & $<<-$ & $\mathrm{HE}$ & 0.262 & 0.071 & 3.684 & 0.000 \\
\hline CONS & $<--$ & IE & 0.263 & 0.074 & 3.546 & 0.000 \\
\hline CONS & $<--$ & RISK & -0.055 & 0.046 & -1.19 & 0.234 \\
\hline \multicolumn{7}{|c|}{ Demographic Differentiation (Female) } \\
\hline IE & <-- & RISK & 0.374 & 0.059 & 6.377 & 0.000 \\
\hline HOEF & $<-$ & IE & 0.758 & 0.074 & 10.218 & 0.000 \\
\hline HOEF & $<<-$ & RISK & -0.177 & 0.044 & -4.033 & 0.000 \\
\hline CONS & $<--$ & $\mathrm{HE}$ & 0.440 & 0.077 & 5.716 & 0.000 \\
\hline CONS & <-- & IE & 0.493 & 0.083 & 5.970 & 0.000 \\
\hline CONS & $<-$ & RISK & -0.128 & 0.039 & -3.252 & 0.001 \\
\hline
\end{tabular}


in individual efficacy, households' efficacy is increased by 0.658 . Risks give a significant negative relationship toward households' efficacy with the -0.121 regression estimate value, and the significance level is $1 \%$. For every single unit increase in risks, households' efficacy is decreased by 0.12 . Households' efficacy has a significant positive effect on the consumption behavior with the regression estimate value of 0.389 , at significance level by 1 per cent. It explained that for every single unit increase in households' efficacy, consumption behavior is increased by 0.389 . Individual efficacy also give significant positive effect towards consumption behavior by explaining that for every single unit increase in individual efficacy, consumption behavior increases by 0.434 . Finally, as regards consumption behavior, for every single unit increase in risks, consumption behavior decreases by 0.109 .

The unstandardized model specification explains the relationship between individual efficacies towards households' efficacy at $66 \%$. The individual efficacy directly affects consumption for $43 \%$, and households' for $39 \%$. All category of fitness indexes (absolute fit and incremental fit) achieve the required level (Byrne, 2010) and (Fleming et al., 2013). Next is the identification of the R-square of the model. For the $\mathrm{R}$-Square $\left(\mathrm{R}^{2}\right)$ explanation, we will look for the standardized model specification, $\mathrm{R}-\mathrm{Square}\left(\mathrm{R}^{2}\right)$ for the CONS is 0.68 . This value previews that model, which consists of three exogenous variables, named, as IE, HE, RISK, which could estimate $68 \%$ of the information in CONS.

Demographic differentiation for the area (urban and rural) explained the relationship between all variables. In details, risks affect individual efficacy, household financial efficacy and consumption are higher in a rural area compare to urban area, while individual efficacy influences the household's financial efficacy and consumption is slightly higher in rural area compared to urban area. But household's financial efficacy effect on consumption decision is higher in an urban area compared to rural area. Interestingly, findings show that the risk and individual financial efficacy have a more important role in financial efficacy level and consumption behavior for households in the rural area compare to an urban area. But household financial efficacy in the rural area has a more substantial on consumption; implicitly, households in rural area are more dependent and accommodate her/his spouse.

For the gender characteristics, female depicts the same relationship of each variables comparing with the whole model, except risks towards consumption behavior that portray an insignificant relationship. For males, risks do not become significant towards individual efficacy and households' efficacy; the same for the risks towards consumption behavior, which implies that males are not considered as an important risk factor in the consumption and financial efficacy compare to females. The findings also show that the risk and financial efficacy as regards female have a higher effect on consumption behavior and financial efficacy compare to males.

The results show that individual efficacy would positively affect households' efficacy. However, when it comes to consumption decision, individual influences consumption more than households' decisions. This seems plausible because individual decision is more independent compare to the household decision, which needs the consideration of his/her household members. It gives the signals that B40 households tend to make personal decisions and still lacks the belief in their spouse when it comes to consumption decision. Risk preference, however, results suggest that the higher risk preference is related to lower consumption decision.

In addition, this indicates that people might postpone their consumption when the risk is higher, because higher risk should be a trade-off with higher benefits. In line with Hassler (1996) who offers an overview that increased risk will decrease the consumption as, logically, consumer will postpone the purchases. By creating such an in-depth view, he pointed out those durable goods are expensive purchases that can hardly be abandoned. Thus, as the waiting time to get all the information relating to the price of durable goods increases, McDonald and Siegel (1986) come up with evidence that waiting time increases risk. To simplify, the higher the risk, the lower the consumption.

\section{Conclusion}

The article investigates the empirical support of the linkages between household's financial efficacy, individual efficacy, risk preference, demography characteristics, and consumption decision behavior. We offer a structural equation modeling (SEM) and research design survey, and unit analysis focusing on bottom income group's households; technique sampling are is multistage sampling cluster and systematic random sample. The sample included 479 households from three states in Peninsular of Malaysia divided into an urban area and rural area, and male and female.

Results show that households' financial efficacy and individual financial efficacy are among the critical factors that explain the households' consumption decision behavior. Also, risk preference, gender and area (rural or urban) of the household determined the consumption decision behavior of the household. Policy implications of these results clearly suggest that financial efficacy, risk preference and demography characteristics are essential to determine the consumption behavior decision. Therefore, the government should take into account these variables in policy development, and companies also should get information regarding the preference of consumers. 


\section{References}

Bandura, A. (1977). Self-efficacy: Toward a Unified Theory of Behavioural Change. Psychological Review, 84, 191-215.

Bandura, A. (1994). Self-efficacy. In: V.S. Ramachaudran (Ed.), Encyclopedia of human behavior, Vol. 4, Academic Press, New York (1994), pp. 71-81.

Bandura, A. (2006). Guide for Constructing Self-Efficacy Scales. In: T. Urdan \& F. Pajares (Eds.). Self-Efficacy Beliefs of Adolescents (pp. 307-337). Charlotte, NC: Information Age Publishing.

Bandura, A., Caprara, G.V, Barbaranelli, C., Regalia, C., \& Scabini, E. (2014). Impact of Family Efficacy Beliefs on Quality of Family Functioning and Satisfaction with Family Life. Applied Psychology: An International Review, 60(3), 421-448

Barberis, N., \& Thaler, R. H. (2002). A Survey of Behavioural Finance. NBER Working Paper No. 9222. Available at: https:// www.nber.org/papers/w9222

Bozoian, S., Rejeski, W. J., \& McAuley, E. (1994). SelfEfficacy Influences Feeling States Associated with Acute Exercise. Journal of Sport \& Exercise Psychology, 16(3), 326-333.

Byrne, B. M. (2010). Structural Equation Modelling with AMOS (2nd ed.). New York, NY: Routledge.

Campbell, J. Y. (2006). Household Finance. The Journal of Finance, 61(4), 1553-1604. https://doi.org/10.1111/j.15406261.2006.00883.x

Chai, A., \& Moneta, A. (2010). Retrospectives: Engel curves. Journal of Economic Perspectives, 24(1), 225-240. https:// doi:10.1257/jep.24.1.225.

Chetty, R., \& Szeidl, A. (2007). Consumption Commitments and Risk Preferences. The Quarterly Journal of Economics, 122, 831-877. 10.1162/qjec.122.2.831.

Comrey, A., \& Lee, H. (1992). A first course in factor analysis. Hillsdale, NJ: Erlbaum.

Pangaribowo, E. H. (2011). Marginality - Addressing the Nexus of Poverty, Exclusion and Ecology. In: von Braun, J. \& Gatzweiler, F. W. (Eds). Consumption Behavior of the Poorest and Policy Implications in Indonesia (pp. 221-237). Dordrecht, Netherlands: Springer.

Fabelo, J.R., Iglesias, S., Cabrera, R., \& Maldonado, M.T. (2013). Tobacco and alcohol consumption among health sciences students in Cuba and Mexico. Medic Review, 15(4), 18-23.

Fakir, A. A. N. M. \& Jusoh, R. (2020). Board Gender Diversity and Corporate Sustainability Performance: Mediating Role of Enterprise Risk Management. Journal of Asian Finance, Economics and Business, 7(6), 351-363. https://doi. org/10.13106/jafeb.2020.vol7.no6.351

Farrell, E., Fry, T. R. L., \& Risse, L. (2016). The Significance of Financial Self-Efficacy in Explaining Women's Personal Finance Behaviour. Journal of Economic Psychology. 54, 89-99. http://dx.doi.org/10.1016/j.joep.2015.07.001
Fleming, M., House, S., Hanson, V. S., Yu, L., Garbutt, J., McGee, R., Kroenke, K., Abedin, Z., \& Rubio, D. (2013). The Mentoring Competency Assessment: Validation of a New Instrument to Evaluate Skills of Research Mentors. Academic Medicine, 88(7), 1002-1008. https://doi:10.1097/ ACM.0b013e318295e298

Forbes, J., \& Kara, S. M. (2010). Confidence Mediates How Investment Knowledge Influences Investing Self-Efficacy. Journal of Economic Psychology, 31, 435-443.

Fornell, C., \& Larcker, D. F. (1981). Evaluating Structural Equation Models with Unobservable Variables and Measurement Error. Journal of Marketing Research, 18(1), 39-50.

Gajjar, N. B. (2013). Factors Affecting Consumer Behavior. International Journal of Research In Humanities and Social Sciences, 1(2), 10-15.

Grabowski, L. J. S., Call, K. T., \& Mortimer, J. T. (2001). Global and economic self-efficacy in the educational attainment process. Social Psychology Quarterly, 64(2), 164-179.

Hassler, J. (1996). Risk and Consumption. Swedish Economic Policy Review. 3(2), 1996.

Hopkins, B. E., \& Todorova, Z. (2014). Gender Dimensions of the U.S. Consumer Borrowing Expansion. Journal of Economic Issues, 48(2), 501-506.

Hussain, M., Anwar, S., \& Huang, S. (2016). Socioeconomic and Demographic Factors Affecting Labor Force Participation in Pakistan. Journal of Sustainable Development, 9(4), 70-79. http://dx.doi.org/10.5539/jsd.v9n4p70

Kahneman, D., Knetsch, J. L., \& Thaler, R. H. (1990). Experimental tests of the endowment effect and the coase theorem. Journal of Political Economy, 98, 1325-1348.

Kalckreuth, U. V., Schmidt, T., \& Stix, H. (2011). Using Cash to Monitor Liquidity: Implications for Payments, Currency Demand, and Withdrawal Behavior. Journal of Money, Credit and Banking, 46(8), 1753-1785. https://doi.org/10.1111/ jmcb. 12165

Kickul, J., Wilson, F. , Marlino, D., \& Barbosa, S. D. (2008). Are Mis-Alignments of Perceptions and Self-Efficacy Causing Gender Gapsin Entrepreneurial Intention among Our Nation's Teens? Journal of Small Business and Enterprise Development, 5(2), 321-335.

Kusairi, S., Sanusi, N.A., Suriyani, M., Shukri, M., \& Zamri, N. (2019). Financial households' efficacy, risk preference and saving behaviour: Lessons from lowerincome households in Malaysia. Economics and Sociology, 12(2), 301-318. doi:10.14254/2071-789X.2019/12-2/18

Lown, J. M. (2011). Development and Validation of A Financial Self-Efficacy Scale. Journal of Financial Counseling and Planning, 22(2), 54-63.

Lown, J. M. (2015). Development and Validation of A Financial Self-Efficacy Scale. Journal of Family and Economic Issues, 36(4), 491-502.

Luszczynska, A., Scholz, U. \& Schwarzer, R. (2005). The General Self-Efficacy Scale: Multicultural Validation Studies, The 
Journal of Psychology, 139(5), 439-457. https://doi. org/10.3200/JRLP.139.5.439-457.

Madden, M. E. (2014). Perceived Control and Power in Marriage: A Study of Marital Decision Making and Task Performance. Amherst, MA: University of Massachusetts Amherst.

Mcdonald, R., \& Siegel, D. (1986). The Value of Waiting to Invest. The Quarterly Journal of Economics, 101(4), 707-727.

McGuire, W. J. (1976). Some Internal Psychological Factors Influencing Consumer Choice. Journal of Consumer Research, 2(4), 302-319. http://dx.doi.org/10.1086/208643

Minuchin, P. (1985). Families and Individual Developemnt: Provocationfromthe Field of Family Therapy. Child Development, 56(2), 289-302.

Nguyen, D. D., \& Pham, M. C. (2018). Search-Based Sentiment and Stock Market Reactions: An Empirical Evidence in Vietnam. Journal of Asian Finance, Economics and Business, 5(4), 45-56. https://doi:10.13106/jafeb.2018.vol5.no4.45

Nolan, M. T., Hughes, M. T., Kub, J., Terry, P. B., Astrow, A., Thompson, R. E., Clawson, L., Texeira, K., \& Sulmasy, D. P. (2009). Development and Validation of the Family DecisionMaking Self-Efficacy Scale. Palliat Support Care, 7(3), 315. https://doi.org/10.1017/S1478951509990241

O'Brien, R. M. (2007). A Caution Regarding Rules of Thumb for Variance Inflation Factors. Quality and Quantity, 41, 673-690.

Phan, D. T. T., Le, V.H. T., \& Nguyen, T. T. H. (2020). Overconfidence Bias, Comparative Evidences between Vietnam and Selected ASEAN Countries. Journal of Asian Finance, Economics and Business, 7(3), 101-113. https://doi.org/10.13106/jafeb.2020. vol7.no3.101

Tabachnick, B. G., \& Fidell, L. S. (2007). Using Multivariate Statistics (5th ed.). New York, NY: Allyn \& Bacon/Pearson Education.

Terano, R., Mohamed, Z., M., Rezai, G. \& Hanum, Z. (2016). Preference for Locally Grown or Imported Fruit Among the Millennial Generation in Johor, Malaysia. Journal of Food Products Marketing, 22(8), 891-904. https://doi.org/10 $.1080 / 10454446.2015 .1072868$
Toukabri, M. \& Ghali, Z. (2014). Commitment Enhancement to an Organic Product through Corporate Social Responsibility (CSR) and the Mediating Role of The Consumers' Emotional Attachment. International Journal of Advanced and Applied Sciences, 4(1), 28-39.

Trent, K. \& South, S. J. (2003). Spousal Alternatives and Marital Relations. Journal of Families Issues, 24(6), 787-810. https:// doi.org/10.1177/0192513X03252779

Ramiah, V., Xu, X., \& Moosa, I. (2015). Neoclassical Finance, Behavioral finance and Noise Traders: A review and assessment of the literature. International Review of Financial Analysis, 41(C), 89-100.

Ramya, N., \& Ali, S. A. (2016). Factors Affecting Consumer Buying Behavior. International Journal of Applied Research, 2(10), 76-80.

Ritter, J. R. (2003). Behavioral Finance. Pacific-Basin Finance Journal, 11(4), 429-437.

Roberts, M. L. (1998). Gender, Consumption and Commodity Culture. The American Historical Review, 103(3), 817-844. https://DOI: 10.2307/2650573

Samuelson, W., \& Zechauser, R. (1988). Status Quo Bias in Decision Making. Journal of Risk and Uncertainty. 1, 7-59.

Scholz, U., Dona, B. G., Sud, S., \& Schwarzer, R. (2002). Is General Self-Efficacy a Universal Construct? European Journal of Psychological Assessment, 18(3), 242-251. https:// doi:10.1027//1015-5759.18.3.242

Shiller, R. J. (1981). Do Stock Prices Move Too Much To Be Justified by Subsequent Changes in Dividends? American Economic Review, 71, 421-436.

Strecher, V. J., DeVellis, B. M., \& Becker, M. H. (1986). The Role of Self-Efficacy in Achieving Health Behavior. Health Education Quarterly, 13(1), 73-92. https://doi: 10.1177/109019818601300108.

Yaari, M. E. (1987). The dual theory of choice under risk. Econometrica, 55, 95-115. 


\section{Appendices}

\section{A. Original items adapted from GSES}

Please respond to the following statements using these response categories: $1=$ totally disagree $2=$ disagree $3=$ undecided $4=$ agree $5=$ totally agree (Items $1,5,8$ and 10 are reverse-scored.)

\begin{tabular}{|c|l|c|}
\hline Item & \multicolumn{1}{|c|}{ Indicator } & Factor Loading \\
\hline 1 & I can always manage to solve difficult problems if I try hard enough. & .581 \\
\hline 2 & It is hard to stick to my spending plan when unexpected expenses arise & .616 \\
\hline 3 & It is challenging to make progress toward my financial goals & .658 \\
\hline 4 & When unexpected expenses occur I usually have to use credit & .682 \\
\hline 5 & I am confident that I could deal efficiently with unexpected events & .744 \\
\hline 6 & When faced with a financial challenge, I have a hard time figuring out a solution & .714 \\
\hline 7 & I lack confidence in my ability to manage my finances & .773 \\
\hline 8 & I can solve most problems if I invest the necessary effort & .798 \\
\hline 9 & I worry about running out of money in retirement & .621 \\
\hline 10 & I can remain calm when facing difficulties because I can rely on my coping abilities & .696 \\
\hline
\end{tabular}

\section{B. The Household Financial Efficacy Scale (HFES)}

Please respond to the following statements using these response categories: $1=$ totally disagree $2=$ disagree $3=$ undecided $4=$ agree $5=$ totally agree.

If I am not able to make a financial decision, I believe in representing my family members (wife/husband, mother/father in law) when I think.

\begin{tabular}{|c|l|c|}
\hline Item & \multicolumn{1}{|c|}{ Indicator } & Factor Loading \\
\hline 1 & $\begin{array}{l}\text { I am sure delegate household (spouse, parent-in-law) to make financial decisions in the event } \\
\text { of unforeseen expenses }\end{array}$ & .634 \\
\hline 2 & $\begin{array}{l}\text { I believe the ability of the household (spouse, parent-in-law) to make progress toward financial } \\
\text { goals }\end{array}$ & $\begin{array}{l}\text { I need the opinion of households (husband/wife, parent-in-law) when I feel difficulty to figure } \\
\text { out solutions related to finance }\end{array}$ \\
\hline 4 & $\begin{array}{l}\text { I trust the household (spouse, parent-in-law) to arrange finance if I have no longer rely on my } \\
\text { own ability }\end{array}$ & .764 \\
\hline
\end{tabular}




\section{Household Consumption Behavior (HCB)}

\section{Panel 1: Durable goods}

\begin{tabular}{|c|l|c|}
\hline Item & \multicolumn{1}{|c|}{ Indicator } & Factor Loading \\
\hline 1 & $\begin{array}{l}\text { I choose the payment (cash/instalment) method because of it easier myself of doing everyday } \\
\text { spend }\end{array}$ & .684 \\
\hline 2 & Cash/instalment payment educate me to be more disciplined & .583 \\
\hline 3 & Payment in cash limits me in making a purchase & .699 \\
\hline 4 & I choose quality home appliances only & .702 \\
\hline 5 & The price being most important factor in the selection of household appliances & .714 \\
\hline 6 & I worry about interest rate and additional charges (hidden) of the instalment method & .629 \\
\hline 7 & I will use the cash/instalment method to purchase all home appliances over next 5 years & .667 \\
\hline
\end{tabular}

\section{Panel 2: Non-Durable goods}

\begin{tabular}{|c|l|c|}
\hline Item & \multicolumn{1}{|c|}{ Indicator } & Factor Loading \\
\hline 1 & $\begin{array}{l}\text { Spend at the traditional/modern market take care my expenses in accordance with financial } \\
\text { planning }\end{array}$ & .576 \\
\hline 2 & I do not take into consideration distance of the market in making a purchase & .623 \\
\hline 3 & l'd come to market that does not charge parking. & .699 \\
\hline 4 & I choose the cheap goods & .629 \\
\hline 5 & I choose branded goods only & .519 \\
\hline
\end{tabular}

\section{Risk Preference}

\begin{tabular}{|c|l|c|}
\hline Item & \multicolumn{1}{|c|}{ Indicator } & Factor Loading \\
\hline 1 & Do you dare to take any risk that relates on financial uncertainty (Daily Risk) & .783 \\
\hline 2 & Do you dare to take any risk that relates on financial uncertainty (Small Risk) & .861 \\
\hline 3 & Do you dare to take any risk that relates on financial uncertainty (Huge Risk) & .842 \\
\hline
\end{tabular}

